\title{
The illicit cigarette market in six South African townships
}

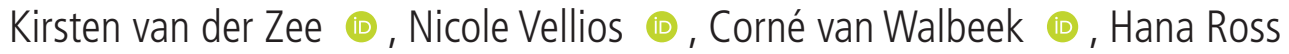

Research Unit on the Economics of Excisable Products, School of Economics, University of Cape Town, Cape Town, South Africa

\section{Correspondence to} Kirsten van der Zee, Research Unit on the Economics of Excisable Products, School of Economics, University of Cape Town, Cape Town 7700, South Africa;

kirsten.vanderzee@uct.ac.za

Received 6 May 2019

Revised 20 September 2019

Accepted 8 November 2019

Published Online First

11 March 2020

\section{ABSTRACT}

Background We estimate the size of the illicit cigarette market in low socioeconomic areas in South Africa before and after a tax increase. In 2018, the real excise tax increased by $3 \%$ and the value-added tax (VAT) rate increased from $14 \%$ to $15 \%$. Thus, the real tax on cigarettes increased by $4 \%$.

Methods A total of 2427 smokers were interviewed over two rounds of data collection (1234 before the tax increase and 1193 after). Data were collected in six townships across four of South Africa's nine provinces. Smokers were asked about their most recent cigarette purchase. Cigarettes purchased for R1 (US\$0.08) or less per stick are presumed illicit, based on a threshold price, which includes production costs and taxes

Results In 2017 and 2018 respectively, 34.6\% and $36.4 \%$ of smokers in the sample purchased illicit cigarettes. The increase in the proportion of illicit purchases was not statistically significant. Smokers with relatively low socioeconomic status, those who have low levels of education and those who are older or unemployed are most likely to purchase illicit cigarettes. Conclusions The illicit cigarette trade in South African townships is widespread. The government should implement an independent track and trace system to curb tax evasion. This would reduce the availability of illicit cigarettes, improve public health and increase excise tax collection.

\section{INTRODUCTION}

The tobacco industry claims that taxes on tobacco products drive the illicit trade of tobacco. ${ }^{1}$ This argument is one that is often used to dissuade governments from increasing excise taxes on tobacco products. Numerous studies have investigated this claim and found a limited relationship between excise taxes and the size of the illicit market. ${ }^{2}{ }^{3}$ Instead, effective monitoring and enforcement have been found to minimise illicit trade even in the presence of tax increases. ${ }^{4-7}$ Effective supply chain management, such as track and trace systems (not controlled by the tobacco industry), has been successful at curbing illicit trade in various countries. ${ }^{8}$

As in many countries, the size of the illicit cigarette market in South Africa has been a matter of fierce debate between academics and the tobacco industry. For many years, academic studies produced estimates significantly below those put forward by the industry. A 2010 paper used government data on excise tax revenue, and combined it with household survey data on smoking prevalence, to calculate the difference between the reported number of cigarettes consumed and official sales. ${ }^{9}$ Using this 'gap analysis' approach, the illegal cigarette market was estimated to have been between $7 \%$ and $11 \%$ of the total market in 2007, which is much lower than the industry's estimate of $20 \%$ at that time. ${ }^{9} 10$

A 2014 academic paper compared the change in legal cigarette sales with the predicted change in total consumption (legal and illegal) to quantify changes in the illicit cigarette market from 1995 to $2012 .{ }^{10}$ The author found no evidence of a substantial change in the illicit share of the market prior to 2009 , as claimed by the tobacco industry, even though tobacco taxes increased by over $200 \%$ in real terms between 1995 and 2009. However, the author found a substantial spike in illegal cigarette consumption in $2010 .^{10}$

Recently, academic estimates of illicit trade have been approaching those of the industry. An updated gap analysis suggested that illegal cigarettes represented between $30 \%$ and $35 \%$ of the total cigarette market in 2017. ${ }^{2}$ Another recent academic study used a nationally representative household survey and a legal price threshold of R20 to estimate illicit trade. The authors found that roughly 30\% of cigarettes consumed in South Africa in 2017 were illicit. ${ }^{11}$ The price threshold method identifies a price point (consisting of costs, profits and taxes) that separates legal cigarettes from illegal cigarettes. The advantage of this method is that it can be applied when price information is available, which is useful when information about the physical features of a pack is either not available or cannot be used to distinguish between legal and illegal cigarettes (as is the case in South Africa). The limitation of the price threshold method is that the results are sensitive to the choice of the threshold price.

In June 2018, the Tobacco Institute of Southern Africa (TISA), a body representing multinational tobacco producers, released results from a commissioned study on the size of illicit trade in South Africa. As with similar studies on illicit trade conducted internationally by the tobacco industry, ${ }^{12}$ the methodological details of TISA's commissioned study were not disclosed. According to the consulting company, Ipsos, a total of 2058 retail outlets were surveyed. Ipsos found that $26.8 \%$ of cigarettes were sold at a price of R17.85 per pack of 20 cigarettes or less, and were, thus, illicit. ${ }^{13} 14$ The threshold price of R17.85 per pack of 20 cigarettes covered the excise tax of R15.52 plus value-added tax (VAT). After another round of data collection in September 2018, Ipsos reported that the proportion of cigarettes sold below the threshold price had increased to $33.1 \% .^{15}$

We use the threshold price methodology, which has been applied elsewhere, ${ }^{16-18}$ to assess the size of the illicit cigarette market in South African 
townships. Townships are underdeveloped and segregated urban areas often spatially disconnected from economic centres and located on the outskirts of major metropolitan areas. Many are characterised by overpopulation, poor service delivery and poor socioeconomic outcomes (including severe poverty and high unemployment). ${ }^{19}{ }^{20}$ Limited law enforcement and high crime rates aid illegal markets, which flourish in these areas. ${ }^{20}{ }^{21} \mathrm{~A}$ 2015 study of the urban residential township of Delft South in the Western Cape provided the first snapshot of the illicit cigarette market in a township. ${ }^{17}$ Roughly, $93 \%$ of the 128 informal outlets included in the study sold cigarettes priced below R18 per pack of 20 (US\$1.36), a price determined by the authors to be so low that it is impossible for all taxes to have been paid. Aside from the Delft study, we are not aware of research on illicit cigarette trade in townships or other low socioeconomic areas (such as rural areas) in South Africa.

In this study, we calculate the share of smokers in our sample whose last cigarette purchase was illicit. We describe the characteristics of township smokers who bought illicit cigarettes using descriptive statistics and regression analysis. To assess whether the tax increase had an impact on the size of illicit cigarette market, we collected data before and after the tax increases (excise and VAT) and conducted the analysis for both periods.

\section{DATA AND METHODS}

The data were collected in two rounds from six townships in four of South Africa's nine provinces: Gauteng (Eldorado Park and Ivory Park), Western Cape (Khayelitsha and Mitchell's Plain), Free State (Thabong) and KwaZulu-Natal (Umlazi). These townships were chosen to represent both the geographical and racial spread of low socioeconomic areas in South Africa. The sample includes two population groups: African and mixed-race (people of mixed Khoisan, Malay, European and black African ancestry). According to the 2017 national survey, smoking prevalence among mixed-race individuals aged $15+$ years was $41 \%$, which is much higher than amongst Africans (14\%). ${ }^{22}$ Our sample does not include Whites since very few Whites live in townships. ${ }^{23}$

Excise taxes in South Africa are set at a national level. In April 2018, the real excise tax on cigarettes increased by $3 \%$ and the VAT rate increased from $14 \%$ to $15 \%$ (for all products). Round 1 data were collected before the taxes increased (October-November 2017), and round 2 data were collected after (July-August 2018). The data collection procedure involved a random walk through each township. A more rigorous sampling methodology was not possible due to budget constraints and safety concerns. We aimed to interview 200 adult smokers (aged $18+$ years) per township per round, each from a unique household. If a household had more than one smoker, a random selection determined which smoker would be interviewed. Approximately, 1200 smokers were sampled in each round.

Respondents were asked about their most recent cigarette purchase, specifically packaging type (single, pack or carton), number of items purchased, brand, type of outlet from where the cigarettes were bought and the amount spent on the cigarettes. Socioeconomic indicators for individuals and households were also collected.

We distinguish licit cigarettes from illicit cigarettes by defining a threshold price, below which it is impossible to sell the product at even a modest profit and cover the taxes and production costs. In the market, the final price of cigarettes is the sum of manufacturing costs, taxes (excise and VAT), distribution costs (producer, wholesaler and retailer) and profits.
Anecdotal evidence from the tobacco industry suggests that a pack of 20 cigarettes can be manufactured for as little as R2.50. ${ }^{24}$ A specific excise tax is applied to every pack of 20 cigarettes, irrespective of the brand, price or any other product feature, and was levied at R14.30 in 2017, rising to R15.52 in 2018. VAT is levied on all costs, including the excise tax. In 2017, VAT on excise was R2.00 (R14.30×14\%) and in 2018, it was R2.33 (R15.52×15\%). Therefore, the minimum tax was R16.30 in 2017 rising to R17.85 in 2018.

We have no information on distribution costs and profits (at the producer, wholesale and retail level), and so do not include them, or the VAT on them, in our threshold price calculations. Our calculation of the threshold price, and by extension, our definition of the illicit market, is therefore extremely conservative.

Costs included in the threshold price are as follows: 2017:

$$
\begin{aligned}
& \mathrm{R} 14.30 \text { (excise) + R2.00 (VAT on excise) + R2.50 } \\
& \text { (manufacturing cost) + R0.35 (VAT on manufacturing cost) }=\text { R19.15 }
\end{aligned}
$$
2018:

$\mathrm{R} 15.52$ (excise) + R2.33 (VAT on excise) + R2.50

(manufacturing cost) + R0.38 (VAT on manufacturing cost) $=$ R20.73

We round off equations (1) and (2) to get a threshold price of R20 per pack (US\$1.51), or R1 per stick (US\$0.08), in 2017 and 2018. We do not vary the threshold price over the period, because retailers in South Africa tend to fix prices at specific points. Surveys on cigarette prices in townships indicate that the vast majority of cheap single sticks are sold for either R0.50 or R1.00. ${ }^{1725}$ A price of R20 in 2017 leaves R0.85 (US\$0.07) per pack for the remaining costs, profits and the VAT payable on these items. A price of R20 in 2018 leaves no margin at all for these remaining items. For context, British American Tobacco's Peter Stuyvesant, the most popular brand in South Africa, retailed for R35 on average in 2018 (R1.75 per stick), irrespective of outlet type. ${ }^{25}$

We can therefore reasonably assume that if a pack was sold for R20 or less in either 2017 or 2018, taxes could not have been paid unless producers were opting to take on a significant loss, which is extremely unlikely. It would have to be a very short-term strategy for the manufacturers or the retailers to carry the taxes by selling the cigarettes at a loss. The illicit trade in these products has been substantial for the 3-4 years prior to our surveys, ${ }^{2}$ a period too long to make this kind of lossleading strategy economically viable. As a sensitivity analysis, we use three other price thresholds: (1) the minimum tax amount (excise plus VAT), $(2)<\mathrm{R} 20$ and $(3) \leq \mathrm{R} 22$.

In a small number of cases, the answers reported by respondents yielded nonsensical cigarette prices. Where possible, we cleaned the data on prices using the African Cigarette Prices (ACP) data set as a guideline. ${ }^{25}$ The ACP is a repeated crosssectional retail survey that collects cigarette prices in several countries, including South Africa. Retail survey data is generally more accurate than consumer data, as respondent recall error is eliminated. ${ }^{26}$ There are 6539 observations from South Africa in round 6 of the ACP (June-July 2018).

The ACP data indicates that a single stick sells for between R0.50 and R4, a 10-pack sells for between R5 and R35, a 20-pack sells for between R8 and R60, and a 30-pack sells for between R12 and R90. Using these observations, we corrected some of our township survey data that yielded nonsensical prices. In total, 32 prices were corrected. In addition, all of the data collected by one fieldworker in Umlazi were deleted (39 
observations) because of data inconsistencies. The final sample included 2427 valid observations.

To ascertain household socioeconomic status (SES), respondents were asked whether the household had electricity, a flush toilet, satellite dish, cellular phone, television, radio, fridge, car, motorbike, washing machine, microwave and stove. A household SES index was created, where 0 indicates access to none of the resources, and 1 indicates access to all of the resources, with each resource weighted equally.

We present various descriptive statistics for both rounds, including average prices, the proportion of purchases below the threshold price and a description of the smokers who purchase illicit cigarettes. We also present a regression analysis to isolate the determinants of illicit purchase, holding other factors constant. The regression is specified as follows:

$\operatorname{logit}\left(\right.$ SmokerIllicit $\left._{i \mathrm{t}}\right)=\beta_{0}+\beta_{1}$ Purchase $_{\mathrm{it}}+\beta_{2}$ Ind $_{\mathrm{it}}+\varepsilon_{\mathrm{it}}$

where SmokerIllict $_{\text {it }}$ is an indicator variable for whether smoker $i$ purchased cigarettes at or below the threshold price of R1 per stick ( 1 if below the threshold price and 0 otherwise). The $t$ subscript indicates the round, where $t=1,2$ or $(1+2)$, where $(1+2)$ is both rounds together. Purchase ${ }_{\text {it }}$ is a vector of characteristics specific to the purchase, including packaging type, township and outlet type. $\operatorname{Ind}_{\mathrm{it}}$ is a vector of individual characteristics, including gender, education, race, employment status, age, the number of cigarettes smoked per day and household SES. We report the odds ratios.

Stata V.14 and Microsoft Excel were used to conduct the analysis.

\section{RESULTS}

\section{Descriptive statistics}

A total of 2427 smokers were interviewed in rounds 1 and 2 (table 1). On average, smokers in round 1 were younger than in round 2 (33.3 years compared with 36.8 years). Round 1 smokers consumed slightly more cigarettes per day (9.7) than round 2 smokers (9.1). These smoking intensity estimates are higher than the estimate of 8.2 cigarettes per day obtained from the 2017 National Income Dynamics Study (NIDS) for a comparable group (low SES, African and mixed-race, and urban smokers). ${ }^{22}$ The gender distribution of our sample is similar to this sample of smokers from NIDS.

More than half of the respondents in both rounds had not completed secondary school. Employment rates were very low: $35.6 \%$ in round 1 and $37.1 \%$ in round 2 . There were only 133

Table 1 Descriptive statistics (total observations in parentheses)

\begin{tabular}{|c|c|c|c|c|}
\hline & & Round 1 & Round 2 & $\%$ Change \\
\hline Total observations & & 1234 & 1193 & -3.3 \\
\hline Age & Average (in years) & 33.3 & 36.8 & $10.6^{* * *}$ \\
\hline Daily cigarette consumption & Average (sticks per day) & 9.7 & 9.1 & $-5.7^{\star}$ \\
\hline Socio-economic status & Average (index 0-1) & 0.73 & 0.7 & $-4.1 * * *$ \\
\hline \multirow[t]{3}{*}{ Proportion } & Male & $69.6(859)$ & $73.1(872)$ & $5.0^{*}$ \\
\hline & Daily smokers & $94.3(1164)$ & $91.6(1093)$ & $-2.9 * * *$ \\
\hline & Female household head & $34.4(425)$ & $39.0(372)$ & $13.3^{* *}$ \\
\hline \multirow[t]{4}{*}{ Education } & None to complete primary school & $11.8(146)$ & $12.3(147)$ & 4.2 \\
\hline & Incomplete secondary school & $42.4(523)$ & $47.8(570)$ & $12.8^{* * *}$ \\
\hline & Complete secondary school & $41.6(513)$ & $33.3(397)$ & $-19.9 * * *$ \\
\hline & Complete tertiary & $4.2(52)$ & $6.5(78)$ & $55.3^{* *}$ \\
\hline \multirow[t]{2}{*}{ Race } & African & $65.2(805)$ & $72.2(859)$ & $10.7^{* * *}$ \\
\hline & Mixed race & $34.8(429)$ & $27.6(329)$ & $-20.5^{* * *}$ \\
\hline \multirow[t]{3}{*}{ Employment status } & Employed & $35.6(437)$ & $37.1(442)$ & 4.4 \\
\hline & Unemployed & $44.1(541)$ & $46.1(549)$ & 4.7 \\
\hline & Not economically active & $19.9(244)$ & $16.6(198)$ & $-16.3^{* *}$ \\
\hline \multirow[t]{6}{*}{ Township } & Eldorado Park (Gauteng) & $17.3(214)$ & $11.1(133)$ & $-35.7 * * *$ \\
\hline & Ivory Park (Gauteng) & $16.0(198)$ & $22.0(263)$ & $37.4^{* * *}$ \\
\hline & Khayelitsha (Western Cape) & $19.0(235)$ & $15.4(184)$ & $-19.0 * *$ \\
\hline & Mitchell's Plain (Western Cape) & $18.5(228)$ & 16.7 (199) & -9.7 \\
\hline & Thabong (Free State) & $15.9(196)$ & $17.0(203)$ & 7.1 \\
\hline & Umlazi (KwaZulu-Natal) & $13.2(163)$ & $17.7(211)$ & $33.9^{* * *}$ \\
\hline \multirow[t]{3}{*}{ Packaging } & Carton & $0.7(9)$ & $0.9(11)$ & 26.4 \\
\hline & Pack & $33.1(408)$ & $40.7(485)$ & $23.0^{* * *}$ \\
\hline & Single & $66.2(817)$ & $58.4(697)$ & $-11.8^{* * *}$ \\
\hline \multirow[t]{6}{*}{ Shop of Cigarette Purchase } & Foreign-owned spaza shopt & $79.6(981)$ & $71.8(839)$ & $-9.9 * * *$ \\
\hline & SA-owned spaza shopt & $8.7(107)$ & $15.0(175)$ & $72.4^{* * *}$ \\
\hline & Spaza shopt (ownership unknown) & $1.5(18)$ & $2.3(27)$ & 58.1 \\
\hline & Retail outlet & $7.2(89)$ & $8.4(98)$ & 16 \\
\hline & Street stand & $0.9(11)$ & $0.8(9)$ & -13.8 \\
\hline & House shop & $2.1(26)$ & $1.7(20)$ & -18.9 \\
\hline
\end{tabular}

SES: 0 indicates access to none of the listed household resources and 1 indicates access to all 12. The statistical test used for the change in proportions is the proportions test. The difference in means test is used for averages.

${ }^{*} p<0.01,{ }^{* *} p<0.05$ and ${ }^{* * *} p<0.001$.

†Spaza shops are informal convenience shops.

SA, South African. 


\begin{tabular}{|c|c|c|c|}
\hline & Round 1 & Round 2 & $\%$ change \\
\hline Overall & $1.64(0.73)$ & $1.63(0.81)$ & -0.74 \\
\hline \multicolumn{4}{|l|}{ Pack type } \\
\hline Carton & $0.99(0.53)$ & $1.00(0.71)$ & 0.80 \\
\hline Pack & $1.45(0.60)$ & $1.36(0.64)$ & $-6.56^{* *}$ \\
\hline Single & $1.74(0.76)$ & $1.82(0.86)$ & $4.88^{* *}$ \\
\hline$P$ value & 0.00 & 0.00 & \\
\hline \multicolumn{4}{|l|}{ Township } \\
\hline Eldorado Park (Gauteng) & $1.68(0.81)$ & $1.59(0.85)$ & -5.32 \\
\hline Ivory Park (Gauteng) & $1.92(0.72)$ & $1.80(0.91)$ & -6.44 \\
\hline Khayelitsha (Western Cape) & $1.71(0.57)$ & $1.57(0.69)$ & $-8.34^{* *}$ \\
\hline Mitchell's Plain (Western Cape) & $1.36(0.53)$ & $1.21(0.53)$ & $-10.90^{* * *}$ \\
\hline Thabong (Free State) & $1.38(0.79)$ & $1.33(0.79)$ & -3.74 \\
\hline Umlazi (KwaZulu-Natal) & $1.83(0.75)$ & $2.16(0.65)$ & $18.09^{* * *}$ \\
\hline$P$ value & 0.00 & 0.00 & \\
\hline \multicolumn{4}{|l|}{ Shop from where cigarettes were bought } \\
\hline Foreign-owned spaza shop $\dagger$ & $1.59(0.73)$ & $1.50(0.83)$ & $-5.65^{* *}$ \\
\hline SA-owned spaza shopt & $1.93(0.79)$ & $2.06(0.75)$ & 7.06 \\
\hline Spaza shop (ownership unknown)† & $1.72(0.79)$ & $2.17(0.71)$ & $26.27^{*}$ \\
\hline Retail outlet & $1.81(0.36)$ & $1.76(0.48)$ & -2.69 \\
\hline Street stand & $2.19(0.66)$ & $1.67(0.78)$ & -23.85 \\
\hline House shop & $1.35(0.80)$ & $1.61(0.82)$ & 19.41 \\
\hline$P$ value & 0.00 & 0.00 & \\
\hline
\end{tabular}

$P$ value from ANOVA test of difference in means of subgroups for pack type, township and shop of purchase within each round.

${ }^{*} p<0.01,{ }^{* *} p<0.05$ and ${ }^{* * *} p<0.001$.

†Spaza shops are informal convenience shops.

ANOVA, analysis of variance; SA, South African.

observations in Eldorado Park in round 2, as data collection was terminated because of safety concerns. To compensate for this, more people were interviewed in Ivory Park (also in Gauteng). The majority of respondents bought cigarettes as single sticks $(66.2 \%$ in round 1 and $58.4 \%$ in round 2$)$. The majority of respondents (round 1: 79.6\% and round 2: 71.8\%) bought cigarettes from foreign-owned spaza shops (small, informal stores). We distinguish between foreign-owned and South Africanowned spaza shops because of their different business models. The foreign-owned spaza shop model tends to be more sophisticated and entrepreneurial, while South African spazas tend to be survivalist in nature. ${ }^{27}$ These differences could result in price variations.

Despite the tax increases, the average price per cigarette (for all packaging types) decreased marginally from R1.64 to R1.63 between rounds 1 and 2; however this change was not statistically significant (table 2 ).

The most expensive way to purchase cigarettes is as singles. Single sticks became almost 5\% more expensive between rounds 1 (R1.74) and 2 (R1.82), significant at the 5\% level. The average price of a pack of 20 cigarettes decreased from R1.45 to R1.36 per stick, also significant at the 5\% level. Since there are very few observations for cartons (9 in round 1 and 11 in round 2), it is not possible to make any meaningful conclusions for this packaging type. In five of the six townships, the average cigarette price declined, with significant decreases in the Western Cape (Mitchell's Plain and Khayelitsha). Prices increased only in Umlazi (KwaZulu-Natal). In both rounds, Mitchell's Plain (Western Cape) and Thabong (Free State) had the cheapest cigarettes. Foreign-owned spaza shops sold the second cheapest cigarettes in round 1 (second to house shops, although this category had only 26 observations), and the cheapest in round 2 , at an average price of R1.59 and R1.50 per stick, respectively.

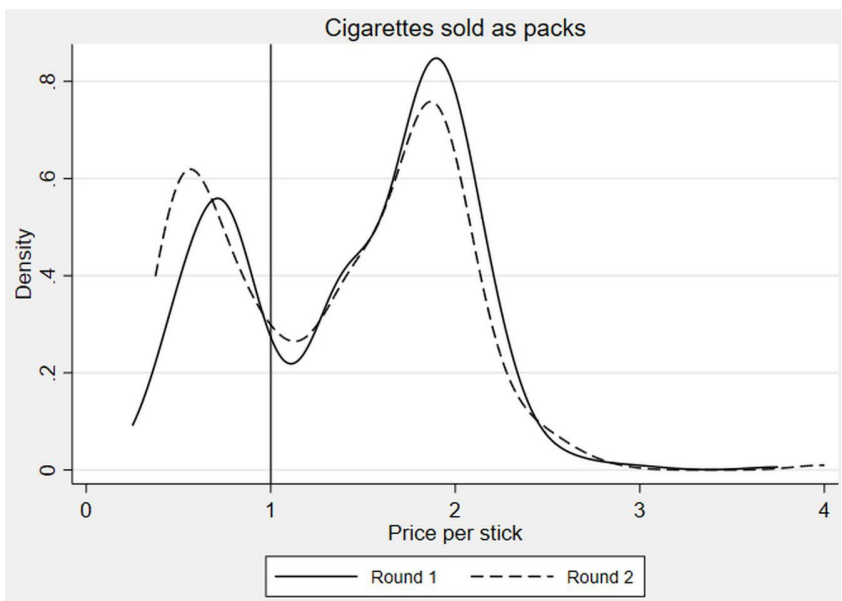

Figure 1 Kernel density plots of cigarette prices. Notes: The vertical line represents R1 per stick, our chosen legal price threshold.

Figures 1 and 2 illustrate the distribution of prices for cigarettes purchased in packs and as singles (cartons are excluded due to the small sample size). Prices of cigarettes sold as packs were bimodal, with peaks at roughly R0.50 and R2 per stick (R10 and R40 per pack of 20 cigarettes, respectively). Single sticks were bought for either around R1 or R2 to R2.50 per stick.

Overall, $34.6 \%$ and $36.4 \%$ of cigarettes bought in rounds 1 and 2, respectively, were illicit (table 3). The increase of 1.8 percentage points $(5.1 \%)$ is not statistically significant. Cigarettes bought in cartons were most likely to be illicit in both rounds. Thabong (Free State) had the highest prevalence of illicit cigarettes: $59.7 \%$ in round 1 and $61.6 \%$ in round 2 . The second highest prevalence was observed in Mitchell's Plain (Western Cape): $40.8 \%$ in round 1 and $47.7 \%$ in round 2 . Besides house shops, which formed only a very small sample, the shop type with the highest proportion of illicit cigarettes was foreignowned spaza shops, with $38.1 \%$ in round 1 and $44.2 \%$ in round 2. A total of $75 \%$ of all respondents bought their cigarettes from foreign-owned spaza shops (1820/2427).

While males bought more illicit cigarettes than females, the difference is not statistically different $(p=0.13$ in round 1 and $p=0.36$ in round 2 ). Smokers with low levels of education and smokers who were unemployed bought the highest proportion

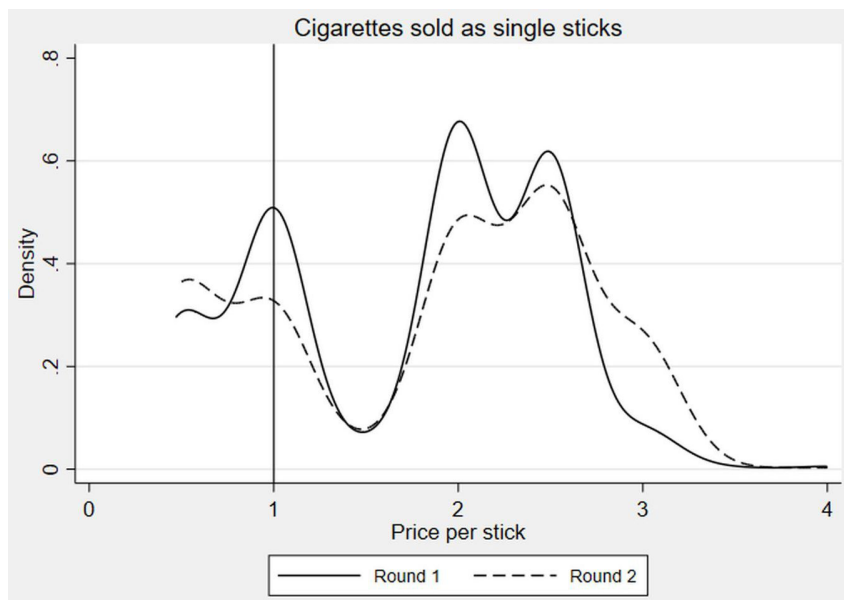

Figure 2 Kernel density plots of cigarette prices. Notes: The vertical line represents R1 per stick, our chosen legal price threshold. 
Table 3 Proportion of cigarettes sold for R1 or less per stick (total observations in parentheses)

\begin{tabular}{|c|c|c|c|}
\hline & Round 1 & Round 2 & $\%$ change \\
\hline Overall & $34.6(1234)$ & $36.4(1193)$ & 5.1 \\
\hline \multicolumn{4}{|l|}{ Pack type } \\
\hline Carton & $55.6(9)$ & $72.7(11)$ & 30.9 \\
\hline Pack & $32.1(408)$ & $38.6(485)$ & 20.1 ** \\
\hline Single & $35.6(817)$ & $34.3(697)$ & -3.7 \\
\hline$P$ value & 0.20 & 0.01 & \\
\hline \multicolumn{4}{|l|}{ Township } \\
\hline Eldorado Park (Gauteng) & $33.2(214)$ & $39.1(133)$ & 17.8 \\
\hline Ivory Park (Gauteng) & 21.7 (198) & $32.3(263)$ & $48.8^{* *}$ \\
\hline Khayelitsha (Western Cape) & $18.7(235)$ & $27.7(184)$ & $48.0^{* *}$ \\
\hline Mitchell's Plain (Western Cape) & $40.8(228)$ & 47.7 (199) & 17.0 \\
\hline Thabong (Free State) & $59.7(196)$ & $61.6(203)$ & 3.2 \\
\hline Umlazi (KwaZulu-Natal) & $36.2(163)$ & $12.3(211)$ & $-66.0 * * *$ \\
\hline$P$ value & 0.00 & 0.00 & \\
\hline \multicolumn{4}{|l|}{ Shop from where cigarettes were bought } \\
\hline Foreign-owned spaza shopt & $38.1(981)$ & $44.2(839)$ & 16.0 *** \\
\hline SA-owned spaza shopt & $26.2(107)$ & $19.4(175)$ & -25.8 \\
\hline Spaza shop (ownership unknown) $†$ & $33.3(18)$ & $14.8(27)$ & -55.6 \\
\hline Retail outlet & $5.6(89)$ & $10.2(98)$ & 81.6 \\
\hline Street stand & $18.2(11)$ & $33.3(9)$ & 83.3 \\
\hline House shop & $46.2(26)$ & $35.0(20)$ & -24.2 \\
\hline$P$ value & 0.00 & 0.00 & \\
\hline \multicolumn{4}{|l|}{ Sex } \\
\hline Male & $36.0(859)$ & $37.2(872)$ & 3.3 \\
\hline Female & $31.5(375)$ & $34.3(321)$ & 8.9 \\
\hline$P$ value & 0.13 & 0.36 & \\
\hline \multicolumn{4}{|l|}{ Education } \\
\hline None to complete primary school & $52.7(146)$ & $64.6(147)$ & $22.5^{* *}$ \\
\hline Incomplete secondary school & $40.3(523)$ & $40.5(570)$ & 0.5 \\
\hline Complete secondary school & $25.5(513)$ & $23.7(397)$ & -7.3 \\
\hline Complete tertiary & $15.4(52)$ & $16.7(78)$ & 8.3 \\
\hline$P$ value & 0.00 & 0.00 & \\
\hline \multicolumn{4}{|l|}{ Race } \\
\hline African & $33.3(805)$ & 33.5 (859) & 0.7 \\
\hline Mixed-race & $37.1(429)$ & $43.8(329)$ & $18.1^{*}$ \\
\hline$P$ value & 0.19 & 0.00 & \\
\hline \multicolumn{4}{|l|}{ Employment status } \\
\hline Employed & $28.8(437)$ & $28.5(442)$ & -1.1 \\
\hline Unemployed & $41.6(541)$ & $41.5(549)$ & -0.1 \\
\hline Not economically active & $28.3(244)$ & 38.4 (198) & $35.7^{* *}$ \\
\hline$P$ value & 0.00 & 0.00 & \\
\hline \multicolumn{4}{|l|}{ Age } \\
\hline Average (in years) & 36.0 & 41.0 & $13.9^{* * *}$ \\
\hline \multicolumn{4}{|l|}{ Daily cigarette consumption } \\
\hline Average (sticks per day) & 10.7 & 10.5 & -2.1 \\
\hline \multicolumn{4}{|l|}{ SES } \\
\hline Average (index 0-1) & 0.69 & 0.65 & $-5.5^{* * *}$ \\
\hline \multicolumn{4}{|c|}{$\begin{array}{l}\text { P value from ANOVA test of difference in means of subgroups within each round. The statistical test } \\
\text { used for the change in proportions is the proportions test. The difference in means test is used for } \\
\text { averages. SES: } 0 \text { indicates access to none of the listed household resources and } 1 \text { indicates access to } \\
\text { all } 12 \text {. } \\
{ }^{*} p<0.01,{ }^{* *} p<0.05 \text { and }{ }^{* * *} p<0.001 \text {. } \\
+ \text { Spaza shops are informal convenience shops. } \\
\text { ANOVA, analysis of variance; SA, South African; SES, socioeconomic status. }\end{array}$} \\
\hline
\end{tabular}

of illicit cigarettes (table 3). However, even smokers with relatively high socioeconomic indicators (eg, employed and tertiary educated) purchased illicit cigarettes. On average, illicit cigarette smokers were older, smoked two or more cigarettes per day and had lower SES than smokers of licit cigarettes (not shown in table).
Table 4 Proportion of cigarette purchases at different price thresholds ( $95 \% \mathrm{Cls}$ in parentheses)

\begin{tabular}{lll}
\hline Price threshold & Round 1 & Round 2 \\
\hline $\begin{array}{l}\text { Tax amount }(<\mathrm{R} 16.30 \text { in round } 1 \text { and } \\
<\text { R17.85 in round } 2)\end{array}$ & $18.5(16.4 ; 20.7)$ & $24.4(22.0 ; 26.9)$ \\
$<$ R20 & $19.6(17.5 ; 21.9)$ & $24.9(22.5 ; 27.4)$ \\
$\leq$ R20 (chosen threshold price) & $34.6(32.0 ; 37.3)$ & $36.4(33.7 ; 39.2)$ \\
$\leq$ R22 & $34.7(32.1 ; 37.4)$ & $36.5(33.8 ; 39.2)$ \\
\hline
\end{tabular}

Table 4 provides a sensitivity analysis for the choice of the threshold price. Since R20 per pack (R1 per stick) is a popular price point (figures 1 and 2), our choice to include R20 or not impacts our estimates of illicit trade. When the tax amount $(<\mathrm{R} 16.30$ in round 1 and $<\mathrm{R} 17.85$ in round 2$)$ and $<\mathrm{R} 20$ are used as threshold prices, the illicit trade estimates decrease by between 11.5 and 16.1 percentage points, compared to the $\leq$ R20 chosen threshold price. Since a threshold price of R20 and less is extremely conservative (barely enough to cover excise tax, VAT, manufacturing and distribution costs, and profit), we are confident that a price of R20 or less should be considered illicit. Illicit trade estimates using a threshold price of $\leq \mathrm{R} 22$ increase only marginally compared with $\leq \mathrm{R} 20$.

\section{Regression analysis}

Table 5 presents multiple regression analysis results for the determinants of illicit cigarette purchases for the full sample, and for rounds 1 and 2 separately. Accounting for observable factors, packs and single sticks were significantly less likely to be illicit than cartons. In round 1, cigarettes purchased in Khayelitsha and Ivory Park were less likely to be illicit than those purchased in Eldorado Park (the base category), while cigarettes purchased in Thabong were more likely to be illicit than those purchased in Eldorado Park; however, there were no significant differences by township in the second round. Cigarettes from foreign-owned spaza shops were significantly more likely to be illicit than those from South African-owned spaza shops and formal retail outlets.

For the overall sample, and in round 2, males were significantly more likely to purchase illicit cigarettes than females. Older smokers, and smokers with a higher consumption per day, had a higher probability of purchasing illicit cigarettes, all else held constant. For all specifications, having higher SES and education levels decreased the likelihood that township smokers purchased illicit cigarettes. Unemployed smokers were significantly more likely to purchase illicit cigarettes than employed smokers, holding all else constant.

\section{DISCUSSION}

We estimate that approximately one-third of the cigarette market in our sample is illicit. We would expect that illicit trade in townships would be higher than national estimates since low SES smokers might be more likely to buy cheap cigarettes and because of weak law enforcement. However, our estimates correspond with two recent national academic studies. ${ }^{211}$ This suggests that illicit trade is not concentrated in townships, but rather that it is ubiquitous across South Africa.

Using a gap analysis method, the first academic study finds the illicit cigarette market to be between $30 \%$ and $35 \%$ of the total market in $2017 .^{2}$ Using a threshold price method, the second paper finds that approximately $30 \%$ of cigarettes were illicit in 2017. ${ }^{11}$ We share the findings of the second paper that smokers of illicit cigarettes have relatively low SES, low levels 
Table 5 Determinants of illicit cigarette purchases (odds ratios)

\begin{tabular}{|c|c|c|c|}
\hline & Overall & Round 1 & Round 2 \\
\hline Carton & 1.00 & 1.00 & 1.00 \\
\hline \multirow[t]{2}{*}{ Pack } & $0.21^{* * *}$ & $0.17^{*}$ & $0.25^{*}$ \\
\hline & $(0.13)$ & $(0.15)$ & $(0.19)$ \\
\hline \multirow[t]{2}{*}{ Single } & $0.24^{* *}$ & $0.18^{*}$ & 0.29 \\
\hline & $(0.14)$ & $(0.17)$ & $(0.22)$ \\
\hline Eldorado Park (Gauteng) & 1.00 & 1.00 & 1.00 \\
\hline \multirow[t]{2}{*}{ Ivory Park (Gauteng) } & $0.32^{* *}$ & $0.32^{* *}$ & 0.10 \\
\hline & $(0.17)$ & $(0.18)$ & $(0.20)$ \\
\hline \multirow[t]{2}{*}{ Khayelitsha (Western Cape) } & $0.29^{* *}$ & $0.20^{* * *}$ & 0.15 \\
\hline & $(0.15)$ & $(0.11)$ & $(0.30)$ \\
\hline \multirow[t]{2}{*}{ Mitchell's Plain (Western Cape) } & 1.21 & 1.10 & 1.22 \\
\hline & $(0.20)$ & $(0.25)$ & $(0.34)$ \\
\hline \multirow[t]{2}{*}{ Thabong (Free State) } & 2.20 & $3.19^{* *}$ & 0.56 \\
\hline & $(1.13)$ & $(1.79)$ & $(1.10)$ \\
\hline \multirow[t]{2}{*}{ Umlazi (KwaZulu-Natal) } & 0.54 & 1.13 & 0.07 \\
\hline & $(0.29)$ & $(0.64)$ & (0.14) \\
\hline Foreign-owned spaza shopt & 1.00 & 1.00 & 1.00 \\
\hline \multirow[t]{2}{*}{ SA-owned spaza shop† } & $0.40^{* * *}$ & $0.50^{* *}$ & $0.48^{* * *}$ \\
\hline & $(0.07)$ & $(0.14)$ & $(0.13)$ \\
\hline \multirow[t]{2}{*}{ Spaza shop (ownership unknown)† } & 0.55 & 1.97 & 0.31 \\
\hline & $(0.26)$ & $(1.02)$ & $(0.26)$ \\
\hline \multirow[t]{2}{*}{ Retail outlet } & $0.12^{* * *}$ & $0.10 * * *$ & $0.14^{* * *}$ \\
\hline & $(0.04)$ & $(0.05)$ & $(0.06)$ \\
\hline \multirow[t]{2}{*}{ Street stand } & 0.56 & 0.39 & 0.85 \\
\hline & $(0.34)$ & $(0.36)$ & $(0.82)$ \\
\hline \multirow[t]{2}{*}{ House shop } & 1.04 & 1.93 & 0.79 \\
\hline & $(0.34)$ & $(0.93)$ & $(0.39)$ \\
\hline Female & 1.00 & 1.00 & 1.00 \\
\hline \multirow[t]{2}{*}{ Male } & $1.50^{* * *}$ & 1.27 & $1.88^{* * *}$ \\
\hline & $(0.18)$ & $(0.21)$ & $(0.34)$ \\
\hline $\begin{array}{l}\text { No education to complete primary } \\
\text { school }\end{array}$ & 1.00 & 1.00 & 1.00 \\
\hline \multirow[t]{2}{*}{ Incomplete secondary school } & $0.66^{* *}$ & $0.64^{*}$ & $0.67^{*}$ \\
\hline & $(0.11)$ & $(0.15)$ & $(0.16)$ \\
\hline \multirow[t]{2}{*}{ Complete secondary school } & $0.44^{* * *}$ & $0.40^{* * *}$ & $0.45^{* * *}$ \\
\hline & $(0.08)$ & $(0.10)$ & $(0.12)$ \\
\hline \multirow[t]{2}{*}{ Complete tertiary } & $0.25 * * *$ & $0.18^{* * *}$ & $0.34^{* * *}$ \\
\hline & $(0.08)$ & $(0.08)$ & $(0.14)$ \\
\hline African & 1.00 & 1.00 & 1.00 \\
\hline \multirow[t]{2}{*}{ Mixed-race } & 0.76 & 0.80 & 0.28 \\
\hline & $(0.38)$ & $(0.43)$ & $(0.56)$ \\
\hline Employed & 1.00 & 1.00 & 1.00 \\
\hline \multirow[t]{2}{*}{ Unemployed } & $1.65^{* * *}$ & $1.72^{* * *}$ & $1.54^{* * *}$ \\
\hline & $(0.19)$ & $(0.29)$ & $(0.26)$ \\
\hline \multirow[t]{2}{*}{ Not economically active } & 0.87 & 0.78 & 0.93 \\
\hline & $(0.13)$ & $(0.16)$ & $(0.22)$ \\
\hline \multirow[t]{2}{*}{ Age } & $1.03^{* * *}$ & $1.03^{* * *}$ & $1.03^{* * *}$ \\
\hline & $(0.00)$ & $(0.01)$ & $(0.01)$ \\
\hline Daily cigarette consumption & $1.03^{* * *}$ & $1.02^{*}$ & $1.04^{* * *}$ \\
\hline & $(0.01)$ & $(0.01)$ & $(0.01)$ \\
\hline SES (index 0-1) & $0.09 * * *$ & $0.08^{* * *}$ & $0.05^{* * *}$ \\
\hline & $(0.03)$ & $(0.04)$ & $(0.02)$ \\
\hline Constant & $16.21^{* * *}$ & $24.06^{* * *}$ & $51.61^{*}$ \\
\hline & $(13.88)$ & $(28.78)$ & $(111.01)$ \\
\hline Observations & 2371 & 1213 & 1158 \\
\hline
\end{tabular}

Robust SEs in parentheses. The dependent variable is equal to 1 if the individual purchased cigarettes for R1 or less, and 0 if not. SES: 0 indicates access to none of the listed household resources and 1 indicates access to all 12 .

${ }^{*} \mathrm{p}<0.01,{ }^{* *} \mathrm{p}<0.05$ and ${ }^{* * *} \mathrm{p}<0.001$.

tSpaza shops are informal convenience shops.

SA, South African; SES, socioeconomic status. of education and are less likely to be employed. However, even township smokers from relatively high socioeconomic groups purchase illicit cigarettes, which is also consistent with the findings of the second paper. ${ }^{11}$

The 2018 TISA study of illicit trade in South Africa used a threshold price method, defining illicit cigarettes as those retailing for less than R17.85 per pack. The study found that the illicit market share was $26.8 \%$ in June and $33.1 \%$ in September, $2018 .^{28}$

The tobacco industry often claims that taxes are the reason that illicit trade is high and rising. We find no significant change in the size of the illicit market in our sample following the tax increase, although this could be because the increase was small (4\%). Other studies have looked at this relationship in greater detail and have found no link between excise taxes and illicit trade. The illicit cigarette market remained insignificantly small in the period 1995-2009, while excise taxes were increasing rapidly. ${ }^{2}$ In contrast, the illicit cigarette market increased sharply in the 2010-2017 period when the real cigarette excise tax remained largely unchanged. ${ }^{2}$

The size of the illicit cigarette market in South Africa is alarming considering the relatively low levels prior to 2010. After 2014, when a new commissioner was appointed at the South African Revenue Service (SARS), a significant number of senior personnel left the institution and dedicated tax compliance units were shut down. ${ }^{29}$ There have also been allegations of questionable relations between some tobacco companies and high-profile politicians. ${ }^{30} 31$ The upheaval at SARS was so damaging that in 2018 the President of South Africa appointed a commission of inquiry into governance at SARS. Among other things, the findings from the commission and investigative journalists highlight the diminished capacity at SARS to counter illicit trade, specifically in tobacco products, noting revenue losses and evidence of increased illicit activity in the sector. ${ }^{1432}$

The WHO's Protocol to Eliminate Illicit Trade in Tobacco Products (ITP) provides best practices for eliminating illicit trade, including independently operated track and trace systems. Currently, SARS is unable to verify whether or not excise tax has been paid on a pack of cigarettes since SARS only requires a simple and barely visible excise marker that has no security features and is easy to reproduce. SARS has been slow to implement a track and trace system, both due to the industry opposition and administrative challenges at SARS. Although South Africa has not ratified the ITP, in 2018, the Minister of Finance committed the government to implement fiscal markers on cigarette packs. ${ }^{33}$

Aside from a track and trace system, the government could also clamp down on the sale of single cigarettes. Single sticks are popular in townships: 6 out of 10 people bought cigarettes as singles. Smokers may not have R10 or R20 available to buy a pack of 20 cigarettes, but they may have R0.50 or R1 to buy a single stick. If the law banning the sale of single cigarettes were enforced, consumption might fall.

We note several limitations. First, our results are not nationally representative, nor representative of the selected townships. However, our findings are similar to those found in nationally representative studies. ${ }^{211}$ Second, it is possible that we erroneously edited valid data during our data cleaning process. If this is the case, we may have underestimated illicit trade. Even so, the distortionary effect will have been very small, given that we made few price corrections. Third, there may be recall error where respondents do not accurately remember the prices they paid. Fourth, there may be measurement error as respondents may not answer truthfully about whether they are smokers or the number 
of cigarettes they smoke, owing to a perceived stigma associated with smoking. ${ }^{34-36}$ Fifth, with our method, we are unable to identify untaxed cigarettes that are priced above the threshold price. It is possible that some cigarettes were classified as licit when they were in fact illicit. This could have occurred if cigarettes were sold at a high price, but the tax was not paid. This might be a strategy used by the larger players, who have been identified as being significantly involved in the illicit market. ${ }^{2937}$ Sixth, and related to the previous limitation, it is possible that some manufacturers declare a part of their production for tax purposes but do not declare the remainder. If all these cigarettes are sold at the same price and below the threshold price, we would overestimate illicit trade; if they are sold above the threshold price, we would underestimate illicit trade.

\section{CONCLUSION}

The illicit cigarette market is widespread in South African townships. As a result, the government is losing a significant amount of tax revenue. In addition, the public health implications of easy access to low-price cigarettes are devastating: young people are more likely to experiment and to become regular smokers, continuing smokers are likely to smoke more and smokers who would otherwise consider quitting may not do so. To address the illicit cigarette trade, the government needs to control cigarette supply channels, both within the country and from abroad. A track and trace system, independent of the tobacco industry, would help to curb illicit trade at a national level, because all domestic production and official imports would be independently verified. Cigarettes without the required markings would be easy to spot at the place of sale, aiding enforcement. If South Africa were to ratify the Framework Convention on Tobacco Control's Protocol to Eliminate Illicit Trade in Tobacco Products, already ratified by 57 countries (December 2019), ${ }^{38}$ it could draw on technical assistance and international collaboration, offered by the Framework Convention on Tobacco Control's Secretariat, to introduce an effective track and trace system.

\section{What this paper adds}

- Illicit trade is widespread in South African townships: approximately one-third of the cigarettes in the sample were illicit.

- While there are several national estimates of illicit trade, this is the first paper to study illicit trade in low socioeconomic settings in South Africa.

- This is the first study to present a profile of township smokers in South Africa.

Contributors HR conceptualised the study. NV and HR designed the questionnaire. $\mathrm{NV}$ and KvdZ managed data collection. KvdZ conducted the data analysis. All the authors contributed to the writing of the manuscript.

Funding This research was supported by the International Development Research Centre under the Global Alliance for Chronic Diseases research programme (grant ID number: 108442-002 and IRMA 25761), Cancer Research UK (IRMA 25171) and the Bill and Melinda Gates Foundation (through the African Capacity Building Foundation) (IRMA 20177).

Competing interests None declared.

Patient consent for publication Not required.

Provenance and peer review Not commissioned; externally peer reviewed.

Data availability statement Data available on request.

ORCID iDs

Kirsten van der Zee http://orcid.org/0000-0002-1353-8534

Nicole Vellios http://orcid.org/0000-0003-1488-0179
Corné van Walbeek http://orcid.org/0000-0003-0933-435X

Hana Ross http://orcid.org/0000-0001-5799-1915

\section{REFERENCES}

1 Smith KE, Savell E, Gilmore AB. What is known about tobacco industry efforts to influence tobacco tax? A systematic review of empirical studies. Tob Control 2013;22:144-53.

2 Vellios N, Ross H, van Walbeek C. The illicit trade of cigarettes in South Africa: 2002-2017. Tob Control 2020;29:s234-42.

3 Ross H, Vellios N, Batmunkh T, et al. Impact of Tax increases on illicit cigarette trade in Mongolia. Tob Control 2020;29:s251-5.

4 Joossens L, Raw M. Turning off the tap: the real solution to cigarette smuggling. Int J Tuberc Lung Dis 2003;7:214-22.

5 Joossens L, Raw M. Progress in combating cigarette smuggling: controlling the supply chain. Tob Control 2008:17:399-404.

6 Merriman D. Cigarette smuggling does not reduce the public health benefits of cigarette taxes. Appl Econ Lett 2002;9:493-6.

7 International Agency for Research on Cancer. IARC Handbooks of Cancer Prevention, Tobacco Control. 14. Lyon, France: Effectiveness of Tobacco Tax and Price Policies for Tobacco Control, 2011.

8 World Bank. Confronting illicit tobacco trade: a global review of country experiences, 2019. Available: http://documents.worldbank.org/curated/en/677451548260528135/ Confronting-Illicit-Tobacco-Trade-a-Global-Review-of-Country-Experiences [Accessed 18 Feb 2019].

9 Blecher E. A mountain or a molehill: is the illicit trade in cigarettes undermining tobacco control policy in South Africa? Trends Organ Crime 2010;13:299-315.

10 Van Walbeek C. Measuring changes in the illicit cigarette market using government revenue data: the example of South Africa. Tob Control 2014;23:e69-74.

11 Van der Zee K, van Walbeek C, Magadla S. Illicit/cheap cigarettes in South Africa. Trends in Organized Crime 2019;68.

12 Gallagher AWA, Evans-Reeves KA, Hatchard JL, et al. Tobacco industry data on illicit tobacco trade: a systematic review of existing assessments. Tob Control 2019:28:334-45.

13 Ipsos. 2018 national tobacco market survey, 2018. Available: https://web.archive. org/web/20180810125449/http://www.tobaccosa.co.za/wp-content/uploads/IPSOS2018-National-Tobacco-Market-Study-Executive-Summary-1.pdf [Accessed $14 \mathrm{Mar}$ 2019].

14 Van Rensburg D. The rot runs deep in the tobacco sector. fin24, 2018. Available: https://web.archive.org/save/https://www.fin24.com/Economy/South-Africa/the-rotruns-deep-in-the-tobacco-sector-20180708-2 [Accessed 9 Dec 2019].

15 Curson B. An alarming escalation in illicit cigarette trade, 2018. Available: https:// web.archive.org/web/20190201111044/https://www.moneyweb.co.za/moneywebopinion/ipsos-report-shows-alarming-escalation-in-illicit-cigarette-trade/ [Accessed 1 Feb 2019].

16 Iglesias RM, Szklo AS, Souza MCde, et al. Estimating the size of illicit tobacco consumption in Brazil: findings from the global adult tobacco survey. Tob Control 2017;26:53-9

17 Liedeman R, Mackay B. A Smokescreen economy: the nature and scale of the township grey market cigarette trade in Delft, 2015. Available: http://livelihoods.org za/wp-content/uploads/2018/05/A-Smokescreen-Economy-township-grey-marketcigarette-trade-in-Delft_booklet.pdf [Accessed 9 Dec 2019].

18 Maldonado N, Llorente BA, Iglesias RM, et al. Measuring illicit cigarette trade in Colombia. Tob Control 2020;29:s262-8.

19 Rakabe E. Prospects for revitalising township economies: from the fringes to the mainstream. A case study of Tembisa.

20 Mahajan S. Economics of South African townships: special focus on Diepsloot. The World Bank, 2014.

21 Manaliyo J. Townships as Crime 'Hot-Spot' Areas in Cape Town: Perceived Root Causes of Crime in Site B, Khayelitsha. Mediterranean Journal of Social Sciences 2014;5:596-603

22 Southern Africa Labour and Development Research Unit. National Income Dynamics Study 2017, Wave 5 [dataset]. Version 1.0.0 Pretoria: Department of Planning, Monitoring, and Evaluation [funding agency]. Cape Town: Southern Africa Labour and Development Research Unit [implementer]. Cape Town: DataFirst [distributor] 2018.

23 Parry CDH, Plüddemann A, Steyn K, et al. Alcohol use in South Africa: findings from the first Demographic and Health Survey (1998). J Stud Alcohol 2005;66:91-7.

24 Personal communication between Corné van Walbeek and a representative from a multinational tobacco company on 20 November 2018.

25 ACP. African cigarette prices 2016-2018. Data on Alcohol and Tobacco in Africa Project, DataFirst 2019.

26 Ross H. Understanding and measuring tax avoidance and evasion: a methodological guide. Prepared for the Economics of Tobacco Control Project, School of Economics, University of Cape Town and Tobacconomics, Health Policy Center, Institute for Health Research and Policy, University of Illinois at Chicago, 2015. Available: http://www. tobaccoecon.uct.ac.za/etcp/publications/reports [Accessed 15 Oct 2018] 
27 Liedeman R. Understanding the internal dynamics and organisation of Spaza shop operators. University of the Western Cape, [Masters thesis] 2013.

28 Ipsos. 2018 tobacco market survey 2018. Available: https://web.archive.org/web/ 20190311091719/http:/www.tobaccosa.co.za/wp-content/uploads/lpsos-TobaccoMarket-Study-REPORT.pdf [Accessed 15 Mar 2019].

29 Van Loggerenberg J, Lackay A. Rogue: the inside story of SARS's elite crime-busting unit. Jonathan Ball Publishers, 2016.

30 Thamm M. SARS Wars: Health warning - tobacco may be harmful to your democracy. Daily Maverick, 2016. Available: https://web.archive.org/web/ 20160224004551/https://www.dailymaverick.co.za/article/2016-02-23-sars-warshealth-warning-tobacco-may-be-harmful-to-your-democracy/ [Accessed 23 Jan 2019].

31 Gous N. The EFF leader, with the cigarette smuggler, in the affidavit., 2018. Available: https://web.archive.org/web/20190206130942/https://www.businesslive.co.za/bd/ national/2018-07-06-the-eff-leader-with-the-cigarette-smuggler-in-the-affidavit/ [Accessed 6 Feb 2019].
32 Judge Nugent RCommission of inquiry into tax administration and governance by SARS, final report; 2018. http://www.thepresidency.gov.za/

33 National Treasury. Budget review, 2018. Available: http://www.treasury.gov.za/ documents/national\%20budget/2018/review/FullBR.pdf [Accessed 10 Dec 2019].

34 Dietz PM, Homa D, England LJ, et al. Estimates of nondisclosure of cigarette smoking among pregnant and nonpregnant women of reproductive age in the United States. Am J Epidemiol 2011;173:355-9.

35 Roth MA, Aitsi-Selmi A, Wardle $H$, et al. Under-reporting of tobacco use among Bangladeshi women in England. J Public Health 2009;31:326-34.

36 Pérez-Stable EJ, Marín BV, Marín G, et al. Apparent underreporting of cigarette consumption among Mexican American smokers. Am J Public Health 1990;80:1057-61.

37 Van Loggerenberg J. Death and taxes: how SARS made Hitmen, drug Dealers and Tax Dodgers pay their dues. Jonathan Ball Publishers, 2018.

38 World Health Organization. Framework Convention on Tobacco Control. Protocol to Eliminate Illicit Trade in Tobacco Products 2013. 